\title{
INCREASE OF DURABILITY OF TOOLS MADE OF STEEL R6M5 USED FOR PARTS PRODUCTION IN THE AUTOMOTIVE INDUSTRY
}

\author{
T. Khristoforova, Assoc. Prof., Ph. D.(Eng.), O. Kuzmenko, Assoc. Prof., Ph. D. (Eng.), \\ National Polytechnic University «KhPI»
}

\begin{abstract}
The possibility of improving the durability of stamping and cutting tools made of steel R6M5 (M2) for automotive parts manufacturing is considered. It has been shown that the main factor determining the steel properties is the time of the fist tempering under condition that the modes of quenching and of the second tempering are standard.
\end{abstract}

Key words: stamping and cutting tools, high-speed steel, tempering.

\section{ПОВЫШЕНИЕ ДОЛГОВЕЧНОСТИ ИНСТРУМЕНТА ИЗ СТАЛИ Р6М5 ДЛЯ ИЗГОТОВЛЕНИЯ ДЕТАЛЕЙ АВТОМОБИЛЬНОЙ ПРОМЫШЛЕННОСТИ}

\author{
Т.А. Христофорова, доц., к.т.н., Е.А. Кузьменко, доц., к.т.н., \\ Национальный технический университет «ХПИ», г. Харьков
}

\begin{abstract}
Аннотация. Рассмотрена возможность повышения долговечности штампового и режущего инструмента, который используют для изготовления стальных автомобильных деталей. Предложены режимы термообработки, обеспечивающие повышение долговечности службы режущего и штампового инструмента из стали Р6М5.
\end{abstract}

Ключевые слова: инструмент, быстрорежущая сталь, термообработка.

\section{ПІДВИЩЕННЯ ДОВГОВІЧНОСТІ ІНСТРУМЕНТУ ЗІ СТАЛІ Р6М5 ДЛЯ ВИГОТОВЛЕННЯ ДЕТАЛЕЙ АВТОМОБІЛЬНОЇ ПРОМИСЛОВОСТІ}

\author{
Т.А. Хрістофорова, доц., к.т.н., О.О. Кузьменко, доц., к.т.н., \\ Національний технічний університет «ХПІ», м. Харків
}

\begin{abstract}
Анотація. Розглянуто можливість підвищення довговічності штампового та різального інструменту для виготовлення сталевих автомобільних деталей. Запропоновано режими термічної обробки, що забезпечують підвищення довговічності різального та итампового інструменту зі сталі Р6М5.
\end{abstract}

Ключові слова: інструмент, швидкорізальна сталь, термообробка.

\section{Introduction}

Over $70 \%$ of the automotive parts are manufactured using different types of steels by cutting, cold stamping (CST), hot stamping (HST), sheet stamping and so on. The number of products manufactured by CST is growing steadily. This method is used for producing fasteners, bearings balls, rollers, rings, piston pins, balls of suspension and other.
An important advantage of CST is a high factor of material utilization: as compared to casting and HST it saves about $50 \%$ of metal, compared with machining waste chips are reduced 2-3 times. At CST the factor of material utilization reaches $0,9-0,95$. However, machining continues to play a significant role in modern industry. Parts manufactured by CST are often brought to the final form by cutting (ends facing, narrow grooves cutting, drilling of small diameter holes and others). 
The efficiency of steel processing technology depends largely on the resistance of tools. Therefore the increase of tool life is always very important problem. Even a slight increase in simultaneously the strength and toughness gives positive durability effect as for cutting, so for stamping tool, though they work in different conditions. The material of stamps, in addition to high hardness and heat resistance requires high resistance to cyclic compressive- tensile, bending stresses and fatigue limit [1]. As is known, improving all these properties simultaneously can be achieved by structure changing, for example, by heat treatment.

One of the most common steels for cutting and heavily loaded stamping tools remains highspeed steel R6M5 (M2). The standard heat treatment procedure of this steel includes oil quenching from $1220 \pm 5^{\circ} \mathrm{C}$ and double tempering at $560{ }^{\circ} \mathrm{C}$ during 1 hour both for cutting and stamping tool.

To solve the problem of tool life improving varying quenching temperature is not effective, since its increasing leads to the growth of austenitic grains; it's decreasing - to the lowalloyed martensite formation. The final structure and properties in quenched steel are formed during multiple tempering. Therefore his work is dedicated to the influence of different tempering modes on service properties of tools from steel R6M5 (M2).

\section{Analysis of publication}

Numerous studies [2-9] devoted to high speed steel tempering have shown that a change of its mode can significantly affect the hardness, yield and ultimate strength and resistance to brittle fracture, i.e. the mechanical properties which determine the tool service life. Some procedures were proposed for its improvement. The works [2-4] recommended to elevate the temperature of the first tempering and to decrease its duration, articles [5-8] - to reduce the temperature.

The second tempering mode remained practically unchanged and corresponded to standard treatment. But the influence of the first tempering parameters to steel properties after the second tempering was not investigated. The recommendations of the tempering procedure depending on an instrument type are also not available.
The aim of this work is the systematical study of the first tempering modes impact on the structure and service properties of high-speed steel R6M5 (M2) after the second tempering and the formulation of tempering procedure depending on the operating conditions and type of tool.

\section{Purpose and ptoblem statement}

The specimens after quenching were tempered in a salt bath at the temperature range $100-700{ }^{\circ} \mathrm{C}$. The holding time was measured from the moment of reaching prearranged temperature in the specimen's center which was determined preliminary. It was varied from a few seconds up to eight hours with cooling in the air after it. The second tempering was carried out by a standard mode $\left(560^{\circ} \mathrm{C}, 1\right.$ hour $)$.

According to the state standard 9013-59 (ISO 6508-86) the Rockwell hardness was measured on scale C (load 1471N). The compressive yield strength $\sigma_{0,2}$ was evaluated on cylindrical specimens, type III (GOST 25.503-97). The ultimate strength under bending $\sigma_{u}$ was measured on the $6 \times 6 \times 175 \mathrm{~mm}$ specimens by destruction with a bending moment under the concentrated load (GOST 14019-80).

Susceptibility to a brittle fracture was estimated by cracking and cleavage resistance. As an index of cracking resistance the stress intensity factor $K_{l f c}$ was chosen. It was determined with cyclic loading (equipment of the National Science Center «Kharkov Institute of Physics and Technology», National Academy of Sciences, Ukraine). To evaluate the cleavage resistance $R_{c l}$, the temperature of the brittle-ductile transition $t_{b r}$ was used. Since this temperature determination is complicated for high-carbon steel [10], its value was estimated as the temperature at which percent elongation in tension became equal to $0,2 \%$. For $R_{c l}$ estimation there was accepted the value of tension yield strength at the temperature of brittle-ductile transition [11]. Tensile tests were carried out within temperature range of $20-680{ }^{\circ} \mathrm{C}$. The metal structure was examined by optical and electron microscopes. The X-ray diffraction analysis was performed using the diffractometer DRON-3 in the filtered radiation of a chromium anode. The amount of residual austenite, lattice parameters of $\alpha$ - and $\gamma$ phases, and the macrostress level were determined. The heat resistance was evaluated by steel hardness after specimen holding at $600{ }^{\circ} \mathrm{C}$ during four hours. The service life of the cutting 
tool was determined by a number of manufactured parts to its regrinding. The punches resistance was evaluated by a quantity of extruded objects before punches fraction.

\section{Results and discussion}

Hardness changes during the first tempering. Fig. 1 shows the quenched steel hardness depending on the temperature of the first tempering after different holding. Curve 1 can be divide into three specific stages: the primary softening (I), strengthening (II), secondary softening (III).

At stage I hardness decreases from 64.5 HRC (the hardness of quenched steel) to $\sim 62 \mathrm{HRC}$ (without holding), $\sim 61 \mathrm{HRC}$ (5 min holding) and $\sim 59$ HRC (1 hour holding) - curves 1, 2, 3, consequently. The temperature of maximum hardness $(\sim 66 \mathrm{HRC})$ for this holdings are $650{ }^{\circ} \mathrm{C}, 600{ }^{\circ} \mathrm{C}, 560{ }^{\circ} \mathrm{C}$ (curves 12,3 , consequently). So the first tempering at the standard mode $\left(560^{\circ} \mathrm{C}, 1\right.$ hour) assures to the maximum hardness (Fig. 1, curve 3).

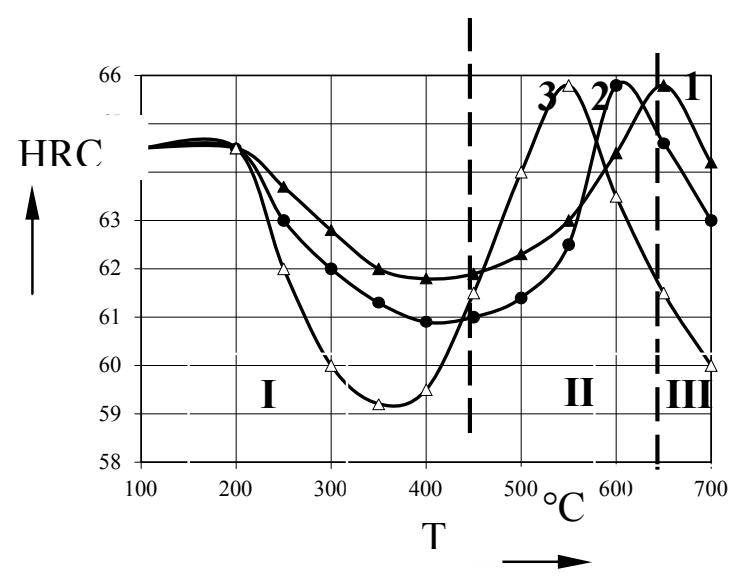

Fig. 1. Hardness change during the first tempering: 1 - without holding; $2-5$ min holding; 3 - 1 hour holding

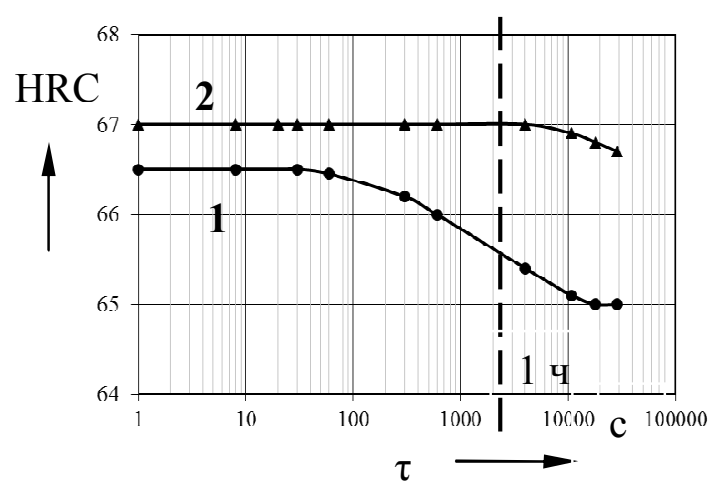

Fig. 2. Hardness after standard second tempering depending on the duration of the first tempering at temperature: $1-560{ }^{\circ} \mathrm{C} ; 2-500{ }^{\circ} \mathrm{C}$
Hardness after the second tempering. It has been found that the specimen hardness after standard second tempering $\left(560{ }^{\circ} \mathrm{C}, 1\right.$ hour) depends on the procedure of the first tempering.

This is shown in Fig. 2 for two temperatures of the first tempering - standard $\left(560^{\circ} \mathrm{C}\right.$, curve 1$)$ and one of the experimental $\left(500{ }^{\circ} \mathrm{C}\right.$, curve 2$)$. As can be seen, at $560{ }^{\circ} \mathrm{C}$ the first hardness value is $66,5 \mathrm{HRC}$ but then it begins to decrease and after 1 hour holding the final hardness is 65,3 HRC. At $500{ }^{\circ} \mathrm{C}$ we can obtain higher final hardness $-67 \mathrm{HRC}$ if the first tempering is interrupted at primary softening stage I (Fig. 1).

It is necessary to underline that such slight increase of hardness can improve the heat resistance significantly. In fact, experimental tempering is the elevated hardness of steel R6M5 after holding at $600{ }^{\circ} \mathrm{C}$ during four hours by 1,5 HRC comparing to the standard mode. As a result, the heat resistance of steel R6M5 reaches the level of steel P18.

As a rule, metal strengthening leads to embrittlement. In this regard, it was important to determine the change of steel resistance to brittle fracture compared to the standard mode. The values of $R_{c l}, K_{l f c}$ and $t_{b r}$ for standard (1) and experimental (2) tempering are given in Table 1. All these data indicate that heat treatment according to the mode 2 increases the steel resistance to brittle fracture.

$\underline{\text { Table } 1} \underline{\text { Indicators of steel resistance to brittle }}$ fracture

\begin{tabular}{|l|l|l|l|l|}
\hline Mode & $\begin{array}{l}\text { Tempering } \\
\text { parameters }\end{array}$ & $\begin{array}{l}K_{l f c}, \\
\text { MПа }\end{array}$ & $\begin{array}{l}R_{c l}, \\
\text { MПa }\end{array}$ & $\begin{array}{l}t_{b r}, \\
{ }^{\circ} \mathrm{C}\end{array}$ \\
\hline 1 & $\begin{array}{l}\text { double temper- } \\
\text { ing, 560 }{ }^{\circ} \mathrm{C}, \\
1 \text { hour }\end{array}$ & 15,2 & 2200 & 550 \\
\hline 2 & $\begin{array}{l}\text { first tempering } \\
500{ }^{\circ} \mathrm{C}, 5 \text { min, } \\
\text { second one - } \\
560{ }^{\circ} \mathrm{C}, 1 \text { hour }\end{array}$ & 20,7 & 2600 & 350 \\
\hline
\end{tabular}

The decrease of hardness on stage I of the first tempering is connected with martensite depletion by carbon due to precipitation of ultrafine $\varepsilon$ carbides $\mathrm{Fe}_{2} \mathrm{C}$ [12].

It's increase at stage II is explained by steel precipitation hardening as a result of retained austenite decomposition and ultrafine special carbides precipitation. Secondary softening at stage III takes place due to carbides coagulation that 
leads to continuing depletion of the matrix by carbon and alloying elements. Naturally, these processes depend on the first tempering duration.

Electron-microscopic investigations have shown that the proposed tempering mode decreases the carbide size from $75 \mathrm{~nm}$ to $40 \mathrm{~nm}$ and increases the uniformity of their distribution in the martensitic matrix. This is followed by enriching of solid solution with allowing elements. The increase of $\alpha$-phase interplanar distance $d_{211}$ from $0,11750 \mathrm{~nm}$ after standard tempering to $0,11768 \mathrm{~nm}$ after the proposed one proves this point of view [12]. The retained austenite is not registered by X-ray method after the second tempering. So, an interruption of the first tempering at the stage of the first softening improves the steel properties. This procedure of the first tempering is recommend for the cutting tool.

\section{Tempering procedure for the stamping tool}

The stamping tool (punches) works in different operating conditions. If punches undergo bending stresses, it is necessary obtain maximum values of $\sigma_{\mathrm{u}}$. If they undergo compressivetensile stresses it is necessary to obtain the maximum resistance to cyclic loading. We applied the principle of choosing the first tempering procedure depending on the type of a tool and loading character. It was found [12] that to obtain high $\sigma_{u}$ the first tempering has to be finished at the stage III of secondary softening (Fig. 1), to reach high cyclic resistance - at the stage of primary softening I.

\section{Industrial testing}

The cutting tool. For cutting tools (drills, multiflute drills, reamers, squaring shear knies) as material being cut there was taken steel 45 , $15 \mathrm{Cr}$, 40Cr, $34 \mathrm{CrMo}$, 36CrMnSiA, stainless steel $12 \mathrm{Cr} 18 \mathrm{Ni} 9 \mathrm{Ti}$ and $\mathrm{Cr} 17 \mathrm{NiMo} 3$. As it was found, the tool resistance was increased at least 2-3 times after treating according to the proposed procedure comparing to the standard one [13]. A particularly remarkable effect was obtained for stainless steel with insufficient machinability. In this case not only the tool life time was doubled, but also the quality of the treated surface was significantly improved.

The stamping tool. The punches resistance was investigated for two-step cold extrusion of bicy- cle brake bushing. Punches at the first extrusion step are destroyed due to bending loads while at the second one - from cyclic compressivetensile stresses. That's why for the first step of extrusion the first tempering was interrupted at the second softening stage, and for the second step - it was interrupted at the first softening stage. It has been found that after such heat treatment the resistance of the first step extrusion punches was increased by 1.6 times, of the second step - by 2 times [14].

Thus, the change of the first tempering procedure greatly improved the resistance both of the cutting and stamping tools made of steel R6M5. It is natural to assume that the developed principal of options of the first tempering procedure depending on the tool type and operating conditions can be applied to the entire class of highspeed steel with carbide strengthening.

\section{Conclusions}

The main cause determining the properties of steel R6M5 is the option of the time-temperature procedure of the first tempering if the modes of quenching and second tempering are fixed.

The principle of choosing the first tempering procedure depending on the type of a tool and the loading character is proposed. For tools which should have high hardness, the yield strength in compression, resistance to brittle fracture and heat resistance the first tempering has to be interrupted at the stage of primary softening. For tools which require high resistance to bending loads the first tempering should be completed at the stage of secondary softening.

Termination of the first tempering at the stage of primary softening allows to refine almost twice the carbides of tempering that simultaneousty increases both the strength and resistance to brittle fracture.

\section{References}

1. Разрушающие напряжения и термическая обработка пуансонов обратного выдавливания / В.А. Евстратов, Т.А. Оприщенко, А.И. Христофоров, С.С. Дьяченко // Кузнечно-штамповочное производство. - 1995. - № 8. - С. 21-22.

2. Лунева 3. С. Влияние кратковременного нагрева при отпуске на свойства закаленной быстрорежущей стали: материа- 
лы Семинара по обмену опытом работников ЦЗЛ и технологов горячих цехов инструментальных заводов. (5-8 октября 1971 г.) / З. С. Лунева. - М.: 1971. C. $58-65$.

3. Смольников Е. А. Сокращенный отпуск быстрорежущих сталей / Е. А. Смольников, В. В. Уманец // Металловедение и термическая обработка металлов. 1980. - № 2. - C. 11-15.

4. А. с. 496399 (61) СССР, М. Кл. С 21Д 1/18. Способ отпуска сталей с вторичным мартенситным превращением / И.К. Купалова-Ярополк (СССР). №2049821/22-2; заяв. 06.08.74; опубл. 25.12.75, Бюл. №47.

5. Павлова Л.П. Влияние отпуска на дисперсионное твердение быстрорежущих сталей / Л.П. Павлова, Ю.А. Геллер // Металловедение и термическая обработка металлов. - 1967. - № 4. - С. 4344.

6. Александрович Б. Л. Особенности термической обработки быстрорежущей стали Р6М5 / Б. Л. Александрович // Металловедение и термическая обработка металлов. - 1972. - № 11. - С. 15-18.

7. А. с. Р 1368336 СССР, кл. С 21D 9/22. Способ термической обработки быстрорежущей стали / П.С. Ушаков, В.А. Колпаков, В.П. Деев и др. (СССР). № 4137088/23-02; заявл. 07.07.86; опубл. 30.07 .88 , Бюл. №28.

8. А. с. 7972244 СССР, кл. С 21D 9/22. Способ термической обработки вольфрамовых и вольфрамомолибденовых быстрорежущих сталей / Ю.С. Ушаков, В.А. Колпаков, В. П. Деев и др. (СССР). № 4124019/22-02; заявл. 04.07.86; опубл. 23.01.86, Бюл. №3.

9. Акимов В.В. Повышение свойств быстрорежущей стали для режущего инструмента / В.В. Акимов, П.В. Петунин, О.Ю. Бургонова // Омский научный вестник. Машиностроение и машиноведение. - 2014. - № 2. - С. 27-30.

10. Дьяченко С.С. Физические основы прочности металлов / С.С. Дьяченко, В.Б. Рабухин. - Х.: Вища школа. Изд-во при Харьк. ун-те, 1982. - 200 с.

11. Мешков Ю.Я. Структура металла и хрупкость стальных изделий / Ю.Я. Мешков, Г.А. Пахаренко. - К.: Наукова думка, 1985. -268 с.

12. Роль параметров первого отпуска в повышении стойкости инструмента из ста- ли Р6М5 / Т.А. Оприщенко, С.С. Дьяченко, Е.А. Кузьменко и др. // Нові матеріали і технології в металургії та машинобудуванні. - 2011. - Вип. 2. C. 34-37.

13. Пат. № 19205 Украина, МПК 5 C 21D 9/22. Спосіб термічної обробки швидкорізальної сталі / Шумаков Ю. І. та ін.; заявник: Харківський політехнічний інститут; власник патенту: Опріщенко Т.А. - № 96240209; заявл. 24.09.1993; опубл. 25.12.1997 // Бюл. - 1997. - №6.

14. Кузьменко Е.А. Факторы, определяющие стойкость штампов холодного выдавливания / Е.А. Кузьменко, В.И. Кузьменко, Т.А. Христофорова // Вісник НТУ «ХПІ». - Серія: Інноваційні технології та обладнання обробки матеріалів у машинобудуванні та металургії. 2016. - № 31 (1203). - С. 50-56.

\section{References}

1. Evstratov V.A., Oprischenko T.A., Hristoforov A.I., Dyachenko S.S. Razrushayuschie napryazheniya i termicheskaya obrabotka puansonov obratnogo vyidavlivaniya [Destructive stress and heat treatment of punches for reverse extrusion]. Kuznechnoshtampovochnoe proizvodstvo. 1995. no. 8. pp. 21-22.

2. Luneva Z.S. Vliyanie kratkovremennogo nagreva pri otpuske na svoystva zakalennoy byistrorezhuschey stali: materialyi Seminara po obmenu opyitom rabotnikov TsZL i tehnologov goryachih tsehov instrumentalnyih zavodov [Influence of the brief heating at tempering on properties of quenched high-speed steel] (5-8 oktyabrya 1971 g.). Moscow, 1971. pp. 58-65.

3. Smolnikov E.A., Umanets V.V. Sokraschennyiy otpusk byistrorezhuschih staley [Brief vacation of high-speed steel]. Metallovedenie $i$ termicheskaya obrabotka metallov. 1980. № 2. pp. 11-15.

4. A.s. 496399 (61) SSSR, M. K1. S 21D 1/18. Sposob otpuska staley $s$ vtorichnyim martensitnyim prevrascheniem [Method of tempering of steels with secondary martensite transformation]. I.K. KupalovaYaropolk.

5. Pavlova L.P., Geller Yu. A. Vliyanie otpuska na dispersionnoe tverdenie byistrorezhuschih staley [Influence of tempering on the dispersible hardening of high-speed steel]. Metallovedenie $i$ termicheskaya 
obrabotka metallov. 1967. no. 4. pp. $43-44$.

6. Aleksandrovich B.L. Osobennosti termicheskoy obrabotki byistrorezhuschey stali R6M5 [Features of heat treatment of highspeed steel of P6M5]. Metallovedenie $i$ termicheskaya obrabotka metallov. 1972. no. 11. pp. 15-18.

7. A.s. R 1368336 SSSR, kl. S 21D 9/22. Sposob termicheskoy obrabotki byistrorezhuschey stali [Method of heat treatment of high-speed steel] P. S. Ushakov, V. A. Kolpakov, V. P. Deev i dr.

8. A.s. 7972244 SSSR, kl. S 21D 9/22. Sposob termicheskoy obrabotki volframovyih i volframomolibdenovyih bistrorezhuschey staley [Method of heat treatment tungsten and tungstenmolibdenic high-speed steel] / Yu.S. Ushakov, V.A. Kolpakov, V.P. Deev i dr.

9. Akimov V.V., Petunin P.V., Burgonova O. Yu. Povyishenie svoystv byistrorezhuschey stali dlya rezhuschego instrumenta [Increase of properties of high-speed steel for the cutting tools]. Omskiy nauchnyiy vestnik. Mashinostroenie $i$ mashinovedenie. 2014. no. 2. pp. 27-30.

10. Dyachenko S.S., Rabuhin V.B., Dyachenko S.S. Fizicheskie osnovyi prochnosti metallov [Physical bases of metals strength]. Kharkov, Vischa shkola. Izd-vo pri Hark. un-te. Publ., 1982. 200 p.
11. Meshkov Yu.Ya., Paharenko G. A. Struktura metalla i hrupkost stalnyih izdeliy [Structure of metal and fragility of steel product]. Kiev, Naukova dumka Publ., 1985. 268 p.

12. Oprischenko T.A., Dyachenko S.S., Kuzmenko E.A. Rol parametrov pervogo otpuska $v$ povyishenii stoykosti instrumenta iz stali R6M5 [First tempering parameter role in increasing resistance of tools from steel R6M5]. Novi materiali i tehnologiyi $v$ metalurgiyi ta mashinobuduvanni. 2011. vol. 2. pp. 34-37.

13. Pat. № 19205 Ukrayna, MPK 5 C 21 D 9/22. Sposib termichnoi obrobky shvydkorizalnoi stali [Method of heat treatment of highspeed steel] / Shumakov Iu.I. ta in.; Zayavnik: Kharkivskiy Politechnichniy institute; vlasnik patentu: Oprishchenko T.A. № 96240209;

14. Kuzmenko E.A., KuzmenkoV.I., Hristoforova T.A. Faktoryi, opredelyayuschie stoykost shtampov holodnogo vyidavlivaniya [Factors determining resistance of cold extrusion stamps]. Visnik NTU «HPI». Seriya: Innovatsiyni tehnologiyi ta obladnannya obrobki materialiv $u$ mashinobuduvanni ta metalurgiyi. 2016. no. 31 (1203). pp. 50-56.

Рецензент: С.С. Дьяченко, профессор, д.т.н., ХНАДУ. 